\title{
PULVERIZED FUEL ASH SOLIDIFICATION/STABILIZATION OF WASTE: COMPARISON BETWEEN BENEFICIAL REUSE OF CONTAMINATED MARINE MUD AND SEDIMENT
}

\author{
Ivan Y. TANG ${ }^{a}$, Dickson Y. S. YAN ${ }^{b}$, Irene M. C. LO ${ }^{a}$ and Tongzhou LIU \\ ${ }^{a}$ Department of Civil and Environmental Engineering, The Hong Kong University \\ of Science and Technology, Hong Kong, China \\ ${ }^{b}$ Faculty of Science and Technology, Technological and Higher Education Institute \\ of Hong Kong, Hong Kong, China \\ 'Harbin Institute of Technology Shenzhen Graduate School, Shenzhen Key Laboratory of Water Resource \\ Utilization and Environmental Pollution Control, Shenzhen 518055, China
}

Received 5 Nov. 2014; accepted 18 Feb. 2015

\begin{abstract}
This study aimed to maximize the utilization of contaminated marine mud and sediment for beneficial reuse by solidification/stabilization (S/S) treatment with cement and pulverized fuel ash (PFA). For the purposes of waste maximization and enhancing the mechanical property of the S/S mixtures, mixing $75 \%$ by mass of either contaminated marine mud or sediment with $20 \%$ and 5\% of cement and PFA, respectively, was found to be the optimal mix design. Their unconfined compressive strengths reached up to 8.32 $\mathrm{MPa}$ and 4.47 MPa, respectively. Apart from the mechanical property, according to the U.S.EPA, the TCLP results show that all regulated heavy metals were immobilized to a safe level and are available for engineering application such as fill material. The results of XRD reveal that the formation of $\mathrm{CSH}$ gel in the S/S treated mud and sediment is responsible for the strength development and heavy metal immobilization.
\end{abstract}

Keywords: cement, compressive strength, fill material, heavy metal immobilization, TCLP.

\section{Introduction}

Solidification/stabilization (S/S) is a widely used technology to treat contaminated soils in many countries, so as to minimize the level of contaminant leaching prior to landfill disposal. Cement has been intensively utilized as the binder for $S / S$ treatment due to its low material cost and abundance in resources (Ubbrìco, Calabrese 1998; Conner 1999; Gong, Bishop 2003). To further reduce the treatment cost and promote the concept of green remediation, partial replacement of cement with pulverized fuel ash (PFA), which is the residue resulting from the coal combustion process, has been applied to S/S technology recently for the purpose of engineering applications such as road bases (Lav et al. 2006; Ghosh, Dey 2009) and concrete products (Siddique 2004; Durán-Herrera et al. 2011). Apart from the waste utilization and reduction of treatment cost, the use of PFA has been proven to enhance the strength of cement mixed soil (Kogbara et al. 2013) and to reduce the extent of contaminant leaching (Perera, AlTabbaa 2005; Moon et al. 2010). The silica and alumina contents of PFA were considered to play important roles in improving the quality of the S/S treated soil for beneficial reuse, as both silica and alumina react with the calcium hydroxide in cement to form calcium silicate hydrates or calcium aluminium silicate hydrates, which are the main products of cement hydration to provide strength and contaminant binding in cement-based soil (Bouzalakos et al. 2008; Li et al. 2012).

Comparatively, the development of S/S technology in relation to contaminated marine mud and sediment for beneficial reuse is not as comprehensive as that of soil. The high plasticity index of marine mud and sediment was reported to be inversely related to the strength of cement mixture (Saadeldin, Siddiqua 2013) thus limiting most of

Corresponding authors: Dickson Yan, Irene Lo

E-mails: dicksonyan@vtc.edu.hk; irene.lo@ust.hk 
their engineering applications. In addition, the contamination levels of sediment and marine mud are relatively higher than that of coarse soil due to their large surface areas and abundant clay content (Sparks 2003). Two common ways to handle dredged marine mud and sediment are ocean dumping and landfill disposal. With consideration of the adverse environmental impacts, the US Federal regulations - marine protection, research and sanctuaries act of 1972 (MPRSA) have restricted the ocean dumping of dredged sediment from harbours such as those of New York and Newark, and thus left the local port authorities no choice, but an unsustainable option to dispose of the dredged sediment in landfills.

In view of the recent developments of S/S technology, dredged marine mud and sediment indeed can be potentially reused for various construction purposes such as pavement bases (Yan et al. 2014) and fill material (Zhang et al. 2011). Due to the successful strength enhancement of cement mixed soil after the addition of PFA, PFA was recently studied regarding $S / S$ processes in mud and sediment. It was found that PFA can successfully overcome the low strength development of cement mixed sediment and red mud. By mixing $15 \%$ by mass of red mud and $15 \%$ PFA with $53 \%$ cement, the compressive strength of the cement mixture reached up to $35 \mathrm{MPa}$ after 28 days of the curing process (Yao et al. 2013). However, from the sustainability point of view, the percentage of red mud utilization is considered rather low to promote the beneficial reuse of waste. On the contrary, the waste utilization was maximized by $94 \%$ and $3 \%$ by mass of sediment and PFA, respectively, for $S / S$ treatment (Zentar et al. 2012). The unconfined compressive strength of the resulting cementbased material at the $28^{\text {th }}$ day was about $0.6 \mathrm{MPa}$ which may not be enough for most engineering applications. With all the aforementioned concerns, striking a balance between waste maximization and broadened engineering application is believed to be one of the potential perspectives in the sustainable development of S/S treatment for sediment and marine mud.

This study aimed at the maximization of using contaminated sediment and marine mud for beneficial reuse as sustainable fill material by $\mathrm{S} / \mathrm{S}$ treatment with cement and PFA. The physical and mechanical properties and the contaminant leaching behavior of the S/S treated sediment and marine mud was evaluated. In order to provide an in-depth understanding of S/S treated contaminated sediment and marine mud, their performances were compared with the consideration of feasible engineering applications. This study enables further improvements of the S/S technology in relation to contaminated sediment and marine mud, and provides an alternative for sustainable management of dredged sediment and marine mud.

\section{Experimental}

\subsection{Materials}

The contaminated marine mud and sediment were obtained from a contaminated site in Hong Kong. The contaminated marine mud was collected from $10-12 \mathrm{~cm}$ below the ground surface and the contaminated sediment was dredged from 10 to $100 \mathrm{~cm}$ below the seawater/sediment interface. The samples were then sealed in plastic bags, placed in covered buckets and stored in a cold room at $4{ }^{\circ} \mathrm{C}$ to avoid any possible deterioration. Both the contaminated marine mud and sediment were air dried for 2 weeks prior to S/S treatment and then sieved through a $5 \mathrm{~mm}$ size sieve to remove oversized debris. The particle size distribution of the contaminated marine mud and sediment are shown in Figure 1, whereas their physical properties are given in Table 1 . The particle size of the marine mud was smaller than that of sediment, with about $20 \%, 50 \%$ and $30 \%$ of sand, silt and clay for marine mud, and $45 \%, 50 \%$ and $5 \%$ of sand, silt and clay for sediment, respectively. According to the Unified Soil Classification System (ASTM D 2487), the marine mud (with plasticity index of 30.1) and sediment (with plasticity index of 23.2) were classified as $\mathrm{CH}$ (fat clay with sand) and $\mathrm{MH}$ (sandy elastic silt), respectively. Both marine mud and sediment were contaminated and their corresponding heavy metal contents are shown in Table 1. The marine mud was mainly contaminated by $\mathrm{Ba}$ and $\mathrm{Mn}$, with 323.3 and $481.0 \mathrm{mg} / \mathrm{kg}$, respectively. On the other hand, high concentration of $\mathrm{Ba}, \mathrm{Cr}$, $\mathrm{Pb}, \mathrm{Zn}, \mathrm{Mn}$ and especially $\mathrm{Cu}$ were found in the sediment, registering 224.7, 232.3, 152.0, 638.3, 573.3 and $2171.9 \mathrm{mg} / \mathrm{kg}$, respectively.

The cement used was Hong Kong commercially available ordinary Portland cement (OPC) which is equivalent to the American Society Testing and Material (ASTM) type I cement. The pulverized fuel ash used was obtained from a power plant in Hong Kong and is equivalent to the ASTM Class F fly ash. The chemical compositions of OPC

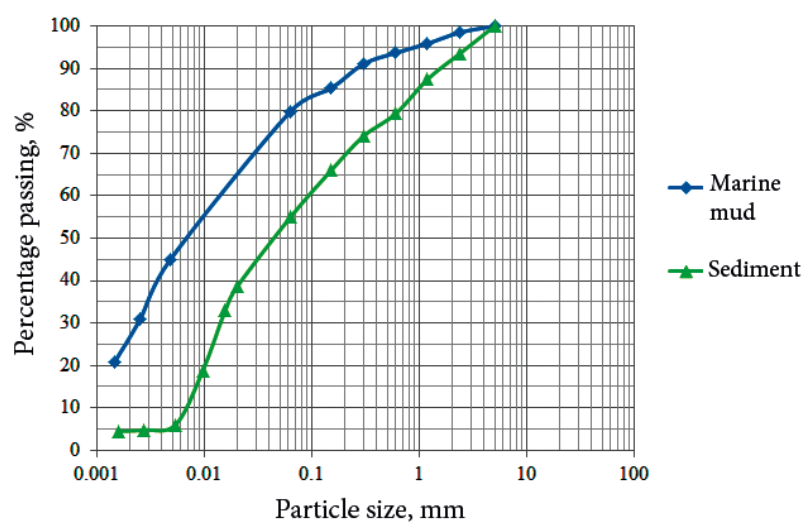

Fig. 1. Particle size distribution of contaminated marine mud and sediment 
Table 1. Physical properties and heavy metal contents of contaminated marine mud and sediment

\begin{tabular}{|c|c|c|}
\hline & Mud & Sediment \\
\hline \multicolumn{3}{|l|}{ Physical properties } \\
\hline Sand $(>63 \mu \mathrm{m})$ (\% by mass) & $20.4 \pm 1.0$ & $45.0 \pm 0.6$ \\
\hline Silt $(63 \sim 2 \mu \mathrm{m})$ (\% by mass) & $49.6 \pm 0.6$ & $50.4 \pm 0.6$ \\
\hline Clay $(<2 \mu \mathrm{m})$ (\% by mass) & $30.0 \pm 1.0$ & $4.6 \pm 0.1$ \\
\hline Moisture Content (\%) & $28.3 \pm 0.92$ & $56.6 \pm 1.27$ \\
\hline $\mathrm{pH}$ & $8.39 \pm 0.04$ & $8.54 \pm 0.03$ \\
\hline Liquid Limit & 50.9 & 52.4 \\
\hline Plastic Limit & 20.8 & 29.2 \\
\hline Plasticity Index & 30.1 & 23.2 \\
\hline Group Symbol & $\mathrm{CH}^{1}$ & $\mathrm{MH}^{2}$ \\
\hline \multicolumn{3}{|c|}{ Heavy metal content (mg/kg by dry weight) } \\
\hline $\mathrm{Sb}$ & $45.7 \pm 3.6$ & $49.1 \pm 5.7$ \\
\hline As & $36.3 \pm 0.9$ & $27.0 \pm 1.9$ \\
\hline $\mathrm{Ba}$ & $323.3 \pm 56.8$ & $224.7 \pm 25.2$ \\
\hline $\mathrm{Cd}$ & $6.0 \pm 3.0$ & $3.8 \pm 0.6$ \\
\hline $\mathrm{Cr}$ & $55.1 \pm 2.4$ & $232.3 \pm 27.5$ \\
\hline $\mathrm{Pb}$ & $51.5 \pm 4.9$ & $152.0 \pm 17.4$ \\
\hline $\mathrm{Hg}$ & $0.9 \pm 0.2$ & $2.3 \pm 0.4$ \\
\hline $\mathrm{Ni}$ & $31.8 \pm 3.6$ & $41.1 \pm 3.1$ \\
\hline $\mathrm{Zn}$ & $98.0 \pm 8.1$ & $638.3 \pm 58.9$ \\
\hline Co & $5.3 \pm 4.4$ & $2.8 \pm 6.4$ \\
\hline $\mathrm{Cu}$ & $18.4 \pm 5.0$ & $2171.9 \pm 117.1$ \\
\hline $\mathrm{Mn}$ & $481.0 \pm 9.2$ & $573.3 \pm 37.5$ \\
\hline Mo & $11.7 \pm 1.8$ & $18.4 \pm 1.8$ \\
\hline Sn & $5.3 \pm 0.2$ & $8.8 \pm 5.5$ \\
\hline
\end{tabular}

${ }^{1} \mathrm{CH}$ refers to clay with a high liquid limit.

${ }^{2} \mathrm{MH}$ refers to silt with a high liquid limit.

Table 2. Chemical compositions of ordinary Portland cement and pulverized fuel ash

\begin{tabular}{ccc}
\hline $\begin{array}{c}\text { Chemical } \\
\text { Composition }\end{array}$ & $\begin{array}{c}\text { Cement } \\
\text { (\% by dry mass) }\end{array}$ & $\begin{array}{c}\text { PFA }^{1} \\
\text { (\% by dry mass) }\end{array}$ \\
\hline $\mathrm{CaO}$ & 65.4 & 13.9 \\
$\mathrm{SiO}_{2}$ & 19.5 & 44.0 \\
$\mathrm{Al}_{2} \mathrm{O}_{3}$ & 3.8 & 17.9 \\
$\mathrm{MgO}$ & 1.5 & 4.7 \\
$\mathrm{Fe}_{2} \mathrm{O}_{3}$ & 3.2 & 13.6 \\
$\mathrm{SO}_{4}$ & 5.3 & 2.5 \\
Loss on ignition & 1.3 & 3.4 \\
\hline
\end{tabular}

${ }^{1}$ PFA refers to pulverized fuel ash. and PFA are shown in Table 2. The OPC comprises $\mathrm{CaO}$, $\mathrm{SiO}_{2}, \mathrm{Al}_{2} \mathrm{O}_{3}$ and $\mathrm{Fe}_{2} \mathrm{O}_{3}$ (i.e. $65.4 \%, 19.5 \%, 3.8 \%$ and $3.2 \%$, respectively), while PFA comprises less $\mathrm{CaO}$ (13.9\%) but more $\mathrm{SiO}_{2}(44.4 \%)$ and fair amounts of $\mathrm{Al}_{2} \mathrm{O}_{3}$ and $\mathrm{Fe}_{2} \mathrm{O}_{3}$ (i.e. $17.9 \%$ and $13.6 \%$, respectively). Potable water was used for the S/S treatment in this study.

\subsection{Preparation of $S / S$ treated contaminated marine mud and sediment}

The design mixes of the S/S treatment for contaminated marine mud and sediment are shown in Table 3. Symbols are used to represent their corresponding materials (i.e. M: mud, S: sediment, C: OPC, F: PFA). For instance, the sample M70C15F15 refers to $70 \%$ mud mixed with $15 \%$ OPC and 15\% PFA. The dry contaminated marine mud and sediment were mixed with OPC and PFA in a mechanical mixer for $2 \mathrm{~min}$ to ensure homogenous mixing. Portable water was then added and mixed with the dry components for another $2 \mathrm{~min}$. Afterwards, the maximum dry density and optimum moisture content of the S/S treated contaminated marine mud and sediment were determined according to the standard Proctor compaction test (BS 1377-4: 1990) as shown in Figures 2a and 2b, respectively, and summarized in Table 3.

Table 3. Mix proportions of S/S treated marine mud and sediment

\begin{tabular}{|c|c|c|c|c|c|}
\hline \multirow[b]{2}{*}{ Sample ID } & \multicolumn{3}{|c|}{ Mass Ratio (\%) } & \multirow{2}{*}{$\begin{array}{c}\text { Water/ } \\
\text { Binder } \\
\text { Mass } \\
\text { Ratio }^{1} \\
\end{array}$} & \multirow{2}{*}{$\begin{array}{c}\text { Maximum } \\
\text { Dry } \\
\text { Density }{ }^{2} \\
\left(\mathrm{~kg} / \mathrm{m}^{3}\right) \\
\end{array}$} \\
\hline & Mud & $\begin{array}{c}\mathrm{Ce}- \\
\text { ment }\end{array}$ & PFA & & \\
\hline M70C15F15 & 70 & 15 & 15 & 0.64 & 1724 \\
\hline M70C10F20 & 70 & 10 & 20 & 0.68 & 1683 \\
\hline M70C5F25 & 70 & 5 & 25 & 0.71 & 1675 \\
\hline M70F30 & 70 & 0 & 30 & 0.73 & 1660 \\
\hline M75C20F5 & 75 & 20 & 5 & 0.64 & 1700 \\
\hline M75C15F10 & 75 & 15 & 10 & 0.66 & 1694 \\
\hline M80C15F5 & 80 & 15 & 5 & 0.63 & 1672 \\
\hline \multirow[b]{2}{*}{ Sample ID } & \multicolumn{3}{|c|}{ Mass Ratio (\%) } & Water/ & Maximum \\
\hline & $\begin{array}{l}\text { Sedi- } \\
\text { ment }\end{array}$ & $\begin{array}{l}\mathrm{Ce}- \\
\text { ment }\end{array}$ & PFA & $\begin{array}{l}\text { Mass } \\
\text { Ratio }^{1}\end{array}$ & $\begin{array}{l}\text { Density } \\
\left(\mathrm{kg} / \mathrm{m}^{3}\right)\end{array}$ \\
\hline S70C15F15 & 70 & 15 & 15 & 0.73 & 1435 \\
\hline S70C10F20 & 70 & 10 & 20 & 0.80 & 1421 \\
\hline S70C5F25 & 70 & 5 & 25 & 0.83 & 1402 \\
\hline S70F30 & 70 & 0 & 30 & 0.84 & 1398 \\
\hline S75C20F5 & 75 & 20 & 5 & 0.83 & 1380 \\
\hline S75C15F10 & 75 & 15 & 10 & 0.86 & 1359 \\
\hline S80C15F5 & 80 & 15 & 5 & 0.83 & 1372 \\
\hline
\end{tabular}

${ }^{1}$ Binder refers to cement and pulverized fuel ash.

${ }^{2}$ Water/Binder ratio is obtained based on the optimum moisture content and maximum dry density of the S/S samples. 
The compacted S/S treated contaminated marine mud and sediment samples were then cast into cubic stainless steel moulds (with a dimension of $50 \times 50 \times 50$ $\mathrm{mm}$ ) with the same effort as the maximum dry density obtained previously in the standard Proctor compaction according to BS EN 12390-2:2009. All S/S samples were prepared in duplicate to show the reproducibility and reliability of the experiments. All samples were demoulded after 1 day and placed in a $100 \%$ relative humidity curing room at room temperature prior to testing.

\subsection{Testing procedures}

The unconfined compressive strength (UCS) of the hardened S/S treated contaminated marine mud and sediment, after curing for 7, 14 and 28 days, was determined according to ASTM D 1633-00, 2000. The UCS of the S/S samples was measured by an automatic compressive testing machine (MTS 815 Test System) at a constant loading rate of $0.1 \mathrm{~mm} / \mathrm{min}$. The experimental data points were plotted with error bars and are reported in terms of mean \pm standard deviation. To provide a better understanding of the strength development of S/S treated contaminated marine mud and sediment, the micro-structural characterization was also studied through X-ray diffraction (XRD) analysis. The samples after curing for 28 days were crushed into powder for investigation of their crystalline information. The XRD analysis was carried out by a Powder X-ray Diffraction System (Philips PW 1830) with an X-ray source scanning the sample between $2 \theta$ angles from $5^{\circ}$ to $80^{\circ}$ at a speed of $0.02^{\circ}$ per minute.

To assess the potential environmental impacts of the $\mathrm{S} / \mathrm{S}$ treated contaminated marine mud and sediment, the heavy metal leachability of the S/S mixtures at the 28th day were studied through toxicity characteristic leaching procedure (TCLP U.S.EPA method 1311). The samples were crushed to a size of less than $1 \mathrm{~cm}$ in diameter and mixed with glacial acetic acid $(\mathrm{pH} 4.93 \pm 0.05)$ at a solid to solution ratio of 1:20 by maintaining an end-over-end rotation of $30 \mathrm{rpm}$ for $18 \mathrm{~h}$. The crushed S/S samples were then separated from the TCLP leachates with 0.45 um cellulose acetate membranes. The heavy metal concentrations of the TCLP leachates were determined by inductively coupled plasma-atomic emission spectroscopy (ICP-AES, Varian 725-ES). All TCLP tests were performed in triplicate and the average concentrations of the leachates were reported with corresponding standard deviations.

\section{Results and discussion}

\subsection{Compaction characteristics of $S / S$ treated marine mud and sediment}

The correlation between maximum dry density and optimum water content of various mixes of S/S treated marine mud and sediment are given in Figures $2 \mathrm{a}$ and $2 b$, respectively. It was found that the optimal water content of S/S treated marine mud and sediment decreased from $21 \%$ to $18.5 \%$ and $24 \%$ to $21.5 \%$, respectively, when their cement content increased from $5 \%$ to $15 \%$ at a fixed amount of marine mud/sediment (i.e. $70 \%$ by mass). Indeed, a similar reduction of optimal water content was also found in a previous study (Zentar et al. 2012) and the reason for such is related to the small specific area of cement. Since the ability of water absorption is proportionally related to the specific area of particles, increasing the amount of cement, which has a smaller specific area compared with that of sediment and marine mud, possibly reduces the optimal water content of the S/S mixtures. Nevertheless, by increasing the amount of cement from $5 \%$ to $15 \%$, the maximum dry densities of the $\mathrm{S} / \mathrm{S}$ mixtures increase. The increase of the maximum dry density with increasing cement content is attributed to the higher specific gravity of the cement (i.e. $3.15 \mathrm{~g} / \mathrm{cm}^{3}$ ) which may benefit the strength
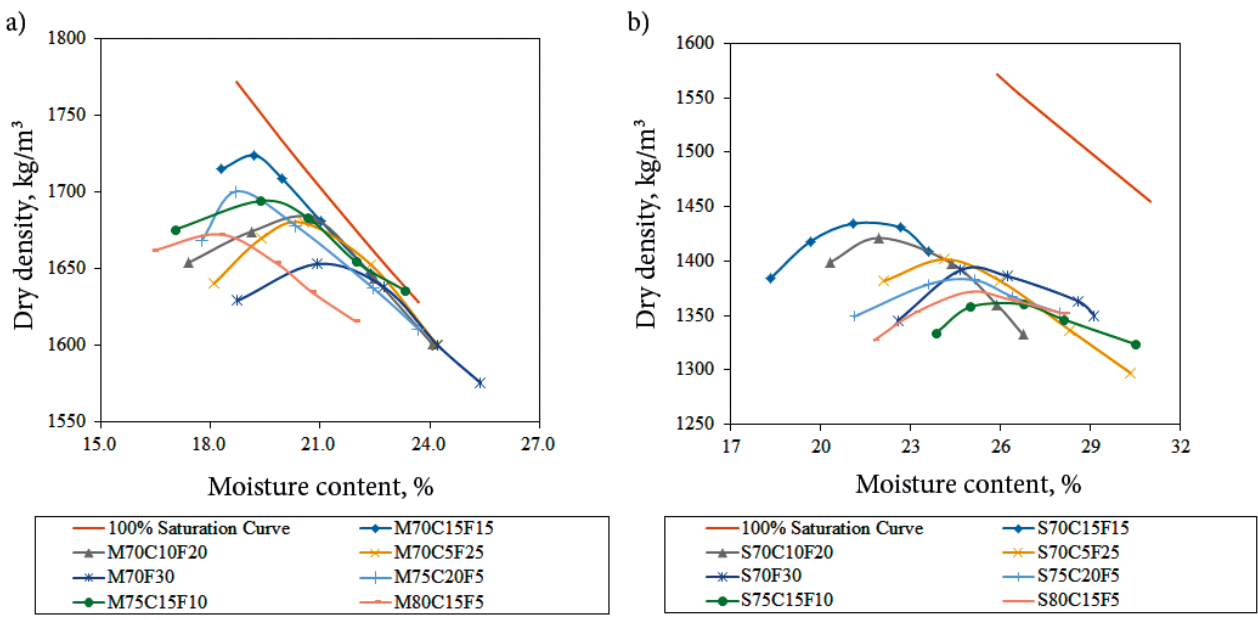

Fig. 2. Compaction curves of (a) S/S treated marine mud and (b) S/S treated sediment 

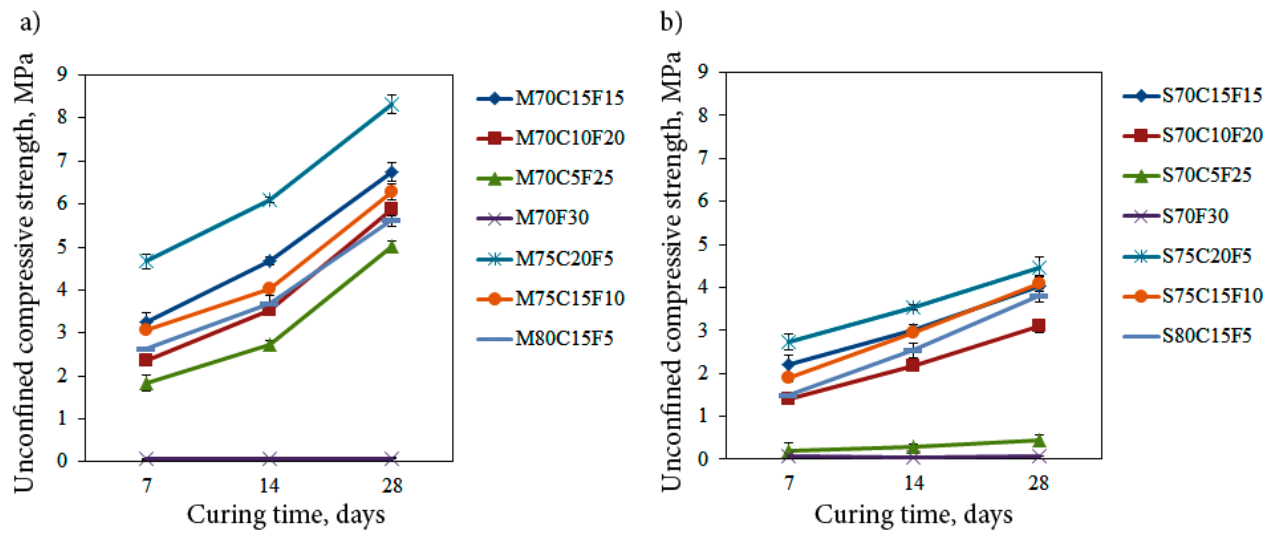

Fig. 3. Unconfined compressive strength of (a) S/S treated marine mud and (b) $S / S$ treated sediment

development of S/S treated marine mud and sediment. However, instead of further increase, the maximum dry densities of both $\mathrm{S} / \mathrm{S}$ treated marine mud and sediment decreased when the cement content increased to $20 \%$ by mass. Since the purpose of this study was to maximize the utilization of marine mud and sediment for S/S treatment so as to enable the reuse of waste for engineering application, the amount of marine mud and sediment increased to $75 \%$ by mass whereas the percentage of cement increased to $20 \%$. It is suspected that the reduction in maximum dry densities of the corresponding $\mathrm{S} / \mathrm{S}$ mixtures is due to the relatively low specific gravity of marine mud and sediment (i.e. $2.65 \mathrm{~g} / \mathrm{cm}^{3}$ ).

\subsection{Unconfined compressive strength of $S / S$ treated marine mud and sediment}

The unconfined compressive strengths of the S/S treated contaminated marine mud and sediment samples at the curing time of 7, 14 and 28 days are given in Figures $3 a$ and $3 b$, respectively, and were found to increase gradually from the $7^{\text {th }}$ to $28^{\text {th }}$ day. In the absence of cement, neither the UCS of PFA-marine mud mixture nor the UCS of PFA-sediment mixture built up with time, even with $30 \%$ by mass of PFA. In addition, by utilizing $70 \%$ by mass of marine mud or sediment, the UCS of the S/S mixtures decreased with increasing amount of PFA (i.e. from $15 \%$ to $25 \%$ by mass). PFA is considered as an alternative of cement due to its pozzolanic components. However, it was found that there was no enhancement in the compressive strength of the S/S mixtures after applying PFA. By comparing the chemical composition between cement and PFA, it was found that the PFA used in this study contained less calcium oxide, but higher silica and alumina contents (Table 2). In view of the essential elements for the formation of C-S-H or C-A-H gel (i.e. $\mathrm{CaO}, \mathrm{SiO}_{2}$ and $\mathrm{Al}_{2} \mathrm{O}_{3}$ ), apparently $\mathrm{CaO}$ is the limiting factor of the PFA used in this study. By increasing the utilization rate of marine mud and sediment from $70 \%$ to $80 \%$ by mass (with $15 \%$ of cement), the UCS at the 28th day reduced from 6.74 to $5.62 \mathrm{MPa}$ and 4.02 to $3.82 \mathrm{MPa}$, for S/S treated marine mud and S/S treated sediment, respectively. As previously discussed, the role of cement in strength development of the $\mathrm{S} / \mathrm{S}$ mixtures is much more significant than that of PFA due to its limited $\mathrm{CaO}$ content. In order to maintain the UCS of the S/S mixtures with increased amounts of marine mud and sediment, more cement is required instead of PFA. In consideration of waste and UCS maximization, $20 \%$ by mass of cement was applied on $75 \%$ marine mud and sediment for S/S treatment, respectively. The corresponding UCS at the $28^{\text {th }}$ day was $8.32 \mathrm{MPa}$ and $4.47 \mathrm{MPa}$, respectively. In view of the various engineering applications, on-site reuse of $S / S$ treated waste as fill material is one of the most common ways to beneficially reuse hazardous waste. According to the U.S.EPA Handbook for Solidification/ Stabilization of Hazardous Wastes (U.S.EPA 540/286/001), the cylinder strength of S/S samples should be at least $1 \mathrm{MPa}$. Assuming that the cube strength of S/S samples is 0.8 times higher than that of the cylinder, the maximum UCS of the designed S/S treated marine mud and sediment samples (i.e. $20 \%, 75 \%$ and $5 \%$ of cement, marine mud/sediment and PFA by mass) satisfied the mechanical requirement for on-site reuse as fill material. To provide a better understanding of the strength development of S/S treated contaminated marine mud and sediment, XRD analysis was performed after 28 days of sample curing and the results are given in Figure 4. For both S/S treated contaminated marine mud and sediment, C-S-H gel dominated the cement hydration product, while a small amount of ettringite was found in the $S / S$ treated contaminated sediment. The result indicates that the strength development of the $\mathrm{S} / \mathrm{S}$ mixtures was mainly contributed by C-S-H gel, but not C-A-H gel. The cement used consists of 3.8\% of $\mathrm{Al}_{2} \mathrm{O}_{3}$, while $17.9 \%$ for PFA (Table 2). Since only $5 \%$ 
by mass of PFA was added, the content of $\mathrm{Al}_{2} \mathrm{O}_{3}$ in the $\mathrm{S} / \mathrm{S}$ mixtures was not enough to form C-A-H gel. Therefore, further study of the different types of PFA may enable improvement of waste utilization and UCS enhancement.

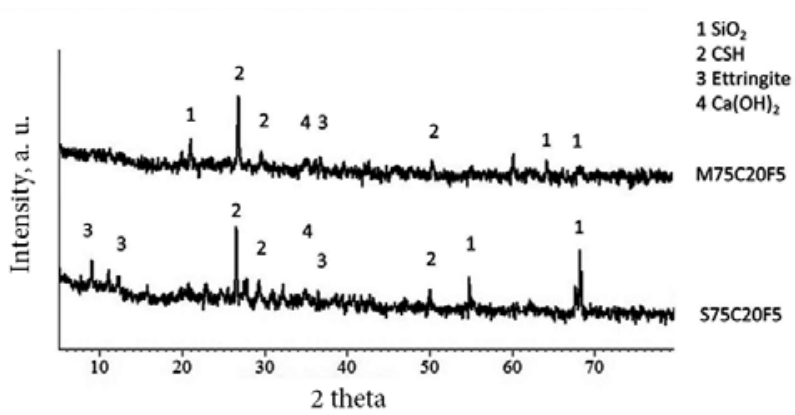

Fig. 4. XRD patterns of $\mathrm{S} / \mathrm{S}$ treated marine mud and $\mathrm{S} / \mathrm{S}$ treated sediment after 28 days of curing.

\subsection{Comparison between marine mud and sediment on UCS after S/S treatment}

Based on the UCS presented in Figure $3 a$ and $3 b$, it can be concluded that $S / S$ treated marine mud performs better than sediment. The maximum UCS obtained by $\mathrm{S} / \mathrm{S}$ treated marine mud is almost double that of sediment (i.e. 8.32 $\mathrm{MPa}$ and $4.47 \mathrm{MPa}$, respectively). In view of the plastic limit of the marine mud and sediment (i.e. 30.1 and 23.2, respectively), the S/S treated marine mud should have a lower UCS than sediment as it was reported that material with a high plastic index tends to possess a low UCS for its S/S mixture (Saadeldin, Siddiqua 2013). It is believed that the high UCS of $\mathrm{S} / \mathrm{S}$ treated marine mud is caused by its high maximum dry density (Table 2) and small particle size (Fig. 1). According to the result of standard Proctor compaction, the average maximum dry density achieved by

Table 4. TCLP results of S/S treated marine mud after 28 days of curing

\begin{tabular}{|c|c|c|c|c|c|c|c|c|c|}
\hline Metals & $\begin{array}{l}\text { TCLP } \\
\text { limits } \\
\text { of UTS } 2 \\
(\mathrm{mg} / \mathrm{L})\end{array}$ & $\begin{array}{c}\text { TCLP } \\
\text { leachate of } \\
\text { marine mud } \\
\text { and PFA } \\
\text { mixture } \\
(\mathrm{mg} / \mathrm{L})\end{array}$ & $\begin{array}{c}\text { M70C15F15 } \\
(\mathrm{mg} / \mathrm{L})\end{array}$ & $\begin{array}{c}\text { M70C10F20 } \\
(\mathrm{mg} / \mathrm{L})\end{array}$ & $\begin{array}{c}\text { M70C5F25 } \\
(\mathrm{mg} / \mathrm{L})\end{array}$ & $\begin{array}{l}\text { M70F30 } \\
(\mathrm{mg} / \mathrm{L})\end{array}$ & $\begin{array}{c}\text { M75C20F5 } \\
(\mathrm{mg} / \mathrm{L})\end{array}$ & $\begin{array}{c}\mathrm{M} 75 \mathrm{C} 15 \mathrm{~F} 10 \\
(\mathrm{mg} / \mathrm{L})\end{array}$ & $\begin{array}{c}\text { M80C15F5 } \\
(\mathrm{mg} / \mathrm{L})\end{array}$ \\
\hline $\mathrm{Sb}(\mathrm{mg} / \mathrm{L})$ & 1.15 & 0.146 & N.D. ${ }^{1}$ & N.D. & N.D. & N.D. & N.D. & N.D. & N.D. \\
\hline As $(\mathrm{mg} / \mathrm{L})$ & 5 & 0.025 & N.D. & N.D. & N.D. & N.D. & N.D. & N.D. & N.D. \\
\hline $\mathrm{Ba}(\mathrm{mg} / \mathrm{L})$ & 21 & 0.172 & $0.89 \pm 0.07$ & $0.86 \pm 0.04$ & $0.97 \pm 0.08$ & $0.65 \pm 0.01$ & $0.31 \pm 0.01$ & $0.70 \pm 0.03$ & $0.64 \pm 0.06$ \\
\hline $\mathrm{Cd}(\mathrm{mg} / \mathrm{L})$ & 0.11 & 0.018 & N.D. & N.D. & N.D. & N.D. & N.D. & N.D. & N.D. \\
\hline $\mathrm{Cr}(\mathrm{mg} / \mathrm{L})$ & 0.6 & 0.037 & N.D. & N.D. & N.D. & N.D. & N.D. & N.D. & N.D. \\
\hline $\mathrm{Pb}(\mathrm{mg} / \mathrm{L})$ & 0.75 & 1.266 & $0.74 \pm 0.04$ & $0.90 \pm 0.01$ & $1.08 \pm 0.12$ & $1.23 \pm 0.09$ & $0.71 \pm 0.09$ & $0.63 \pm 0.06$ & $0.70 \pm 0.03$ \\
\hline $\mathrm{Hg}(\mathrm{mg} / \mathrm{L})$ & 0.025 & 0.022 & N.D. & N.D. & N.D. & N.D. & N.D. & N.D. & N.D. \\
\hline $\mathrm{Ni}(\mathrm{mg} / \mathrm{L})$ & 11 & 0.057 & $0.06 \pm 0.00$ & $0.10 \pm 0.00$ & $0.12 \pm 0.00$ & $0.23 \pm 0.00$ & $0.02 \pm 0.00$ & $0.05 \pm 0.00$ & $0.07 \pm 0.00$ \\
\hline $\mathrm{Zn}(\mathrm{mg} / \mathrm{L})$ & 4.3 & 0.169 & $0.05 \pm 0.00$ & $0.07 \pm 0.00$ & $0.06 \pm 0.00$ & $0.28 \pm 0.00$ & $0.01 \pm 0.00$ & $0.03 \pm 0.00$ & $0.08 \pm 0.00$ \\
\hline Metals & $\begin{array}{l}\text { TCLP } \\
\text { require- } \\
\text { ment } \\
\text { of UTS } \\
(\%)\end{array}$ & $\begin{array}{c}\text { TCLP } \\
\text { leachate of } \\
\text { marine mud } \\
\text { and PFA } \\
\text { mixture } \\
(\mathrm{mg} / \mathrm{L})\end{array}$ & $\begin{array}{c}\text { M70C15F15 } \\
(\%)\end{array}$ & $\begin{array}{c}\text { M70C10F20 } \\
(\%)\end{array}$ & $\begin{array}{c}\text { M70C5F25 } \\
(\%)\end{array}$ & $\begin{array}{c}\text { M70F30 } \\
(\%)\end{array}$ & $\begin{array}{c}\text { M75C20F5 } \\
(\%)\end{array}$ & $\begin{array}{c}\text { M75C15F10 } \\
(\%)\end{array}$ & $\begin{array}{c}\text { M80C15F5 } \\
(\%)\end{array}$ \\
\hline Co $(\%)^{3}$ & $90 \%$ & 0.063 & N.D. & N.D. & N.D. & N.D. & N.D. & N.D. & N.D. \\
\hline $\mathrm{Cu}(\%)^{3}$ & $90 \%$ & 0.010 & N.D. & N.D. & N.D. & N.D. & N.D. & N.D. & N.D. \\
\hline $\operatorname{Mn}(\%)^{3}$ & $90 \%$ & 2.961 & $95.5 \pm 1.6$ & $90.8 \pm 3.0$ & $90.2 \pm 9.1$ & $93.0 \pm 0.1$ & $99.8 \pm 0.1$ & $88.4 \pm 1.9$ & $55.3 \pm 7.1$ \\
\hline $\operatorname{Mo}(\%)^{3}$ & $90 \%$ & 0.038 & N.D. & N.D. & N.D. & N.D. & N.D. & N.D. & N.D. \\
\hline Sn $(\%)^{3}$ & $90 \%$ & 0.004 & N.D. & N.D. & N.D. & N.D. & N.D. & N.D. & N.D. \\
\hline
\end{tabular}

${ }^{1}$ N.D. refers to non-detectable.

${ }^{2}$ UTS refers to Universal Treatment Standards (UTS 40 CFR 268.48).

${ }^{3}$ For $\mathrm{Co}, \mathrm{Cu}, \mathrm{Mn}, \mathrm{Mo}$ and $\mathrm{Sn}$, at least 90 percent reduction in mobility is required after Stabilization/Solidification treatment according to Universal Treatment Standards. 
$\mathrm{S} / \mathrm{S}$ treated marine mud is higher than that of sediment (i.e. 1711 and $1395 \mathrm{~kg} / \mathrm{m}^{3}$ for S/S treated marine mud and sediment with $20 \%$ by mass of cement, respectively). Since marine mud contains more clay portion and it is generally finer than sediment which can easily fill up the void spaces in cementitious material, its strength is thereby increased (Neville 1995).

Apart from their mechanical property, in order to beneficial reuse of contaminated marine mud and sediment, the S/S mixtures have to be minimized as suggested by the U.S.EPA. The TCLP results of S/S treated marine mud and sediment at the $28^{\text {th }}$ day are given in Tables 4 and 5, respectively. The addition of cement to the contaminated marine mud and sediment resulting in a $\mathrm{S} / \mathrm{S}$ matrix shows positive effects on decreasing the mobility of heavy metals. Usage of more than $15 \%$ cement in $70 \%$ and $75 \%$ contaminated marine mud and sediment presents reliable $\mathrm{S} / \mathrm{S}$ effectiveness such that these TCLP results all met the TCLP regulatory standard. Usage of less than $15 \%$ cement in both $70 \%$ and $75 \%$ contaminated marine mud and sediment for S/S treatment were unable to effectively immobilize heavy metals, especially $\mathrm{Pb}$ and $\mathrm{Mn}$. Before the S/S treatment, over hundreds $\mathrm{mg} / \mathrm{kg}$ of $\mathrm{Ba}$ and $\mathrm{Mn}$ was found in the marine mud. The extent of contamination in the sediment was found to be more serious, with over hundreds $100 \mathrm{mg} / \mathrm{kg}$ of $\mathrm{Ba}, \mathrm{Cr}, \mathrm{Pb}, \mathrm{Zn}$ and $\mathrm{Mn}$, and even over two thousands $\mathrm{mg} / \mathrm{kg}$ of $\mathrm{Cu}$. However, with slightly more cement addition (i.e. $20 \%$ cement in both $75 \%$ contaminated marine mud and sediment), the extent of heavy metal leaching was well controlled within the universal treatment standard, especially for $\mathrm{Cu}$ in the sediment with $93 \%$ reduction in its leachability, not posing any adverse health and environmental impacts. Overall of the regulated heavy metals were immobilized.

Table 5. TCLP results of S/S treated sediment after 28 days of curing

\begin{tabular}{|c|c|c|c|c|c|c|c|c|c|}
\hline Metals & $\begin{array}{l}\text { TCLP limits } \\
\text { of UTS }{ }^{2} \\
(\mathrm{mg} / \mathrm{L})\end{array}$ & $\begin{array}{c}\text { TCLP } \\
\text { leachate of } \\
\text { sediment } \\
\text { and PFA } \\
\text { mixture } \\
(\mathrm{mg} / \mathrm{L})\end{array}$ & $\begin{array}{c}\text { S70C15F15 } \\
(\mathrm{mg} / \mathrm{L})\end{array}$ & $\begin{array}{l}\text { S70C10F20 } \\
(\mathrm{mg} / \mathrm{L})\end{array}$ & $\begin{array}{c}\text { S70C5F25 } \\
(\mathrm{mg} / \mathrm{L})\end{array}$ & $\begin{array}{l}\text { S70F30 } \\
(\mathrm{mg} / \mathrm{L})\end{array}$ & $\begin{array}{c}\text { S75C20F5 } \\
(\mathrm{mg} / \mathrm{L})\end{array}$ & $\begin{array}{c}\text { S75C15F10 } \\
(\mathrm{mg} / \mathrm{L})\end{array}$ & $\begin{array}{c}\text { S80C15F5 } \\
(\mathrm{mg} / \mathrm{L})\end{array}$ \\
\hline $\mathrm{Sb}(\mathrm{mg} / \mathrm{L})$ & 1.15 & 0.113 & N.D. ${ }^{1}$ & N.D. & N.D. & N.D. & N.D. & N.D. & N.D. \\
\hline As $(\mathrm{mg} / \mathrm{L})$ & 5 & 0.031 & N.D. & N.D. & N.D. & N.D. & N.D. & N.D. & N.D. \\
\hline $\mathrm{Ba}(\mathrm{mg} / \mathrm{L})$ & 21 & 0.461 & $0.41 \pm 0.07$ & $0.67 \pm 0.03$ & $0.66 \pm 0.02$ & $0.32 \pm 0.00$ & $0.27 \pm 0.01$ & $0.41 \pm 0.03$ & $0.32 \pm 0.01$ \\
\hline $\mathrm{Cd}(\mathrm{mg} / \mathrm{L})$ & 0.11 & 0.043 & N.D. & N.D. & N.D. & N.D. & N.D. & N.D. & N.D. \\
\hline $\mathrm{Cr}(\mathrm{mg} / \mathrm{L})$ & 0.6 & 0.123 & N.D. & N.D. & N.D. & N.D. & N.D. & N.D. & N.D. \\
\hline $\mathrm{Pb}(\mathrm{mg} / \mathrm{L})$ & 0.75 & 0.984 & $0.69 \pm 0.08$ & $0.92 \pm 0.09$ & $0.95 \pm 0.00$ & $0.99 \pm 0.01$ & $0.57 \pm 0.03$ & $0.92 \pm 0.09$ & $0.97 \pm 0.01$ \\
\hline $\mathrm{Hg}(\mathrm{mg} / \mathrm{L})$ & 0.025 & 0.033 & N.D. & N.D. & N.D. & N.D. & N.D. & N.D. & N.D. \\
\hline $\mathrm{Ni}(\mathrm{mg} / \mathrm{L})$ & 11 & 1.388 & $0.14 \pm 0.00$ & $0.25 \pm 0.02$ & $0.63 \pm 0.06$ & $0.91 \pm 0.00$ & $0.11 \pm 0.00$ & $0.13 \pm 0.01$ & $0.09 \pm 0.00$ \\
\hline $\mathrm{Zn}(\mathrm{mg} / \mathrm{L})$ & 4.3 & 13.650 & $0.07 \pm 0.01$ & $0.19 \pm 0.01$ & $3.73 \pm 0.42$ & $8.98 \pm 0.93$ & $0.04 \pm 0.01$ & $0.08 \pm 0.00$ & $0.04 \pm 0.00$ \\
\hline Metals & $\begin{array}{l}\text { TCLP } \\
\text { require- } \\
\text { ment of } \\
\text { UTS } \\
(\%)\end{array}$ & $\begin{array}{c}\text { TCLP } \\
\text { leachate } \\
\text { of marine } \\
\text { mud } \\
\text { and PFA } \\
\text { mixture } \\
(\mathrm{mg} / \mathrm{L})\end{array}$ & $\begin{array}{c}\text { S70C } 15 \mathrm{~F} 15 \\
(\%)\end{array}$ & $\begin{array}{c}\text { S70C10F20 } \\
(\%)\end{array}$ & $\begin{array}{c}\text { S70C5F25 } \\
(\%)\end{array}$ & $\begin{array}{c}\text { S70F30 } \\
(\%)\end{array}$ & $\begin{array}{c}\text { S75C20F5 } \\
(\%)\end{array}$ & $\begin{array}{c}\text { S75C15F10 } \\
(\%)\end{array}$ & $\begin{array}{c}\text { S80C15F5 } \\
(\%)\end{array}$ \\
\hline Co $(\%)^{3}$ & $90 \%$ & 0.085 & N.D. & N.D. & N.D. & N.D. & N.D. & N.D. & N.D. \\
\hline $\mathrm{Cu}(\%)^{3}$ & $90 \%$ & 13.619 & $92.7 \pm 1.0$ & $87.7 \pm 1.0$ & $85.7 \pm 0.5$ & $86.1 \pm 2.1$ & $92.9 \pm 3.3$ & $90.6 \pm 4.1$ & $80.2 \pm 3.1$ \\
\hline $\operatorname{Mn}(\%)^{3}$ & $90 \%$ & 7.954 & $95.3 \pm 5.0$ & $85.3 \pm 3.3$ & $57.3 \pm 3.5$ & $43.5 \pm 1.4$ & $99.9 \pm 0.0$ & $92.8 \pm 4.0$ & $96.6 \pm 1.2$ \\
\hline Mo $(\%)^{3}$ & $90 \%$ & 0.048 & N.D. & N.D. & N.D. & N.D. & N.D. & N.D. & N.D. \\
\hline Sn $(\%)^{3}$ & $90 \%$ & 0.012 & N.D. & N.D. & N.D. & N.D. & N.D. & N.D. & N.D. \\
\hline
\end{tabular}

${ }^{1}$ N.D. refers to non-detectable.

${ }^{2}$ UTS refers to Universal Treatment Standards (UTS 40 CFR 268.48).

${ }^{3}$ For $\mathrm{Co}, \mathrm{Cu}, \mathrm{Mn}, \mathrm{Mo}$ and $\mathrm{Sn}$, at least 90 percent reduction in mobility is required after Stabilization/Solidification treatment according to Universal Treatment Standards. 


\section{Conclusions}

The present study investigated the sustainable and economic management of contaminated marine mud and sediment by mixing them with abandoned PFA in S/S treatment. Based on the result in this study, conclusions are drawn as follows:

1. By increasing the amount of cement from $5 \%$ to $15 \%$ by mass, the optimal water content of the corresponding S/S treated mixture (with $70 \%$ of marine mud and sediment, individually) decreases, but the maximum dry densities increase. However, the increases of either marine mud or sediment in the S/S mixtures decrease their maximum dry densities.

2. The UCS of the S/S treated marine mud and sediment using cement and PFA as binders reached up to $8.32 \mathrm{MPa}$ and $4.47 \mathrm{MPa}$, respectively, at the curing time of 28 days. The UCS achieved enables engineering applications with a high strength requirement. As the most common way to reuse waste, the S/S treated marine mud and sediment qualify as fill material which generally require $1 \mathrm{MPa}$ of UCS.

3. With $15 \%$ by mass of cement, most of the heavy metals were immobilized to acceptable levels, except $\mathrm{Pb}$ and $\mathrm{Mn}$. However, by increasing the amount of cement to $20 \%$ with $5 \%$ of PFA, according to the U.S.EPA, all regulated heavy metals, including $\mathrm{Sb}, \mathrm{As}, \mathrm{Ba}, \mathrm{Cd}, \mathrm{Cr}, \mathrm{Pb}$, $\mathrm{Hg}, \mathrm{Ni}, \mathrm{Zn}, \mathrm{Co}, \mathrm{Cu}, \mathrm{Mn}, \mathrm{Mo}$ and $\mathrm{Sn}$, were successfully immobilized.

4. The results of XRD proved that the formation of $\mathrm{CSH}$ gel in the S/S treated mud and sediment is responsible for the strength development and heavy metal immobilization.

5. For the purposes of waste maximization and enhancing the mechanical property of the S/S mixtures, mixing $75 \%$ by mass of either contaminated marine mud or sediment with $20 \%$ and $5 \%$ of cement and PFA, respectively, were found to be the optimal mix designs to provide a sustainable green remediation alternative in the future.

\section{Acknowledgements}

The authors would like to thank National Natural Science Foundation of China (Grant No. 51208145) for its partial support.

\section{References}

Bouzalakos, S.; Dudeney, A. W. L.; Cheeseman, C. R. 2008. Controlled low-strength materials containing waste precipitates from mineral processing, Mineral Engineering 21: 252-263. http://dx.doi.org/10.1016/j.mineng.2007.09.006

Conner, J. R. 1999. Chemical fixation and solidification of hazardous wastes. New York: Van Nostrand Reihold.
Durán-Herrera, A.; Juárez, C. A.; Valdez, P.; Bentz, D. P. 2011. Evaluation of sustainable high-volume fly ash concretes, Cement and Concrete Composites 33: 39-45. http://dx.doi.org/10.1016/j.cemconcomp.2010.09.020

Ghosh, A.; Dey, U. 2009. Bearing ratio of reinforced fly ash overlying soft soil and deformation modulus of fly ash, Geotext Geomembranes 27: 313-320. http://dx.doi.org/10.1016/j.geotexmem.2008.12.002

Gong, P.; Bishop, P. L. 2003. Evaluation of organics leaching from solidified/stabilized hazardous wastes using a powder reactivated carbon additive, Environmental Technology 24: 445455. http://dx.doi.org/10.1080/09593330309385579

Kogbara, R. B.; Al-Tabbaa, A.; Yi, Y.; Stegemann, J. A. 2013. Cement-fly ash stabilisation/solidification of contaminated soil: Performance properties and initiation of operating envelopes, Applied Geochemistry 33: 64-75. http://dx.doi.org/10.1016/j.apgeochem.2013.02.001

Lav, A. H.; Lav, M. A.; Goktepe, A. B. 2006. Analysis and design of a stabilized fly ash as pavement base material, Fuel 85 : 2359-2370. http://dx.doi.org/10.1016/j.fuel.2006.05.017

Perera, R.; Al-Tabbaa, A. 2005. The role of accelerated carbonation in the accelerated ageing of stabilised/solidified waste forms, in The International Conference of Stabilisation/Solidification Treatment and Remediation, 12-13 April 2005, London, Cambridge, UK, 181-191.

http://dx.doi.org/10.1201/9781439833933.ch23

Siddique, R. 2004. Performance characteristics of high-volume Class F fly ash concrete, Cement and Concrete Research 34: 487-493.

http://dx.doi.org/10.1016/j.cemconres.2003.09.002

Ubbrìaco, P.; Calabrese, D. 1998. Solidification and stabilization of cement paste containing fly ash from municipal solid waste, Thermochimica Acta 321: 143-150. http://dx.doi.org/10.1016/S0040-6031(98)00453-5

Li, X. G.; Lv, Y.; Ma, B. G.; Chen, Q. B.; Yin, X. B.; Jian, S. W. 2012. Utilization of municipal solid waste incineration bottom ash in blended cement, Journal of Cleaner Production 32: 96-100. http://dx.doi.org/10.1016/j.jclepro.2012.03.038

Moon, D. H.; Lee, J. R.; Grubb, D. G.; Park, J. H. 2010. An assessment of Portland cement, cement kiln dust and Class $\mathrm{C}$ fly ash for the immobilization of $\mathrm{Zn}$ in contaminated soils, Environmental Earth Sciences 61: 1745-1750. http://dx.doi.org/10.1007/s12665-010-0596-1

Neville, A. M. 1995. Properties of concrete. $4^{\text {th }}$ ed. UK: Addison Wesley, Longman Limited.

Saadeldin, R.; Siddiqua, S. 2013. Geotechnical characterization of a clay-cement mix, Bulletin of Engineering Geology and the Environment 72: 601-608. http://dx.doi.org/10.1007/s10064-013-0531-2

Sparks, D. L. 2003. Environmental soil chemistry. Amsterdam: Academic Press.

Yan, D. Y. S.; Tang, I. Y.; Lo, I. M. C. 2014. Development of controlled low-strength material derived from beneficial reuse of bottom ash and sediment for green construction, Construction and Building Materials 64: 201-207. http://dx.doi.org/10.1016/j.conbuildmat.2014.04.087

Yao, Y.; Li, Y.; Liu, X.; Jiang, S.; Feng, C.; Rafanan, E. 2013. Characterization on a cementitious material composed of red mud and coal industry byproducts, Construction and Building Materials 47: 496-501. http://dx.doi.org/10.1016/j.conbuildmat.2013.05.030 
Zentar, R.; Wang, D.; Abriak, N. E.; Benzerzour, M.; Chen, W. 2012. Utilization of siliceous-aluminous fly ash and cement for solidification of marine sediments, Construction and Building Materials 35: 856-863.

http://dx.doi.org/10.1016/j.conbuildmat.2012.04.024

Zhang, C. L.; Jin, W.; Wu, X. Y.; Wang, S. C. Properties of solidified dredged sediment used as subgrade construction material, in International Conference on Electric Technology and Civil Engineering, 22-24 April 2011, Lushan, 5774642: 2468-2470.

Standards and Regulations

ASTM D1633-00: 2000. Standard Test Method for Compressive Strength of Molded Soil-cement Cylinders.
ASTM D2487: 2011. Standard Practice for Classification of Soils for Engineering Purposes [Unified soil classification system].

BS EN 12390-2: 2009. Testing hardened concrete. Making and curing specimens for strength tests.

BS 1377-4: 1990. Methods of test for soils for civil engineering purposes. Compaction-related tests.

MPRSA. Marine Protection, Research and Sanctuaries Act of 1972.

U.S.EPA 540/2-86/001: 1986. Handbook for stabilization/solidification of hazardous wastes.

UTS 40 CFR 268.48. Universal treatment standards.

Ivan Y. TANG graduated in Environmental Engineering from Sun Yat-Sen University in 2012. He obtained his Master of Science in 2013 from The Hong Kong University of Science and Technology and is now studying MPhil program at the Department of Civil and Environmental Engineering in the same University. Research interests: solid waste treatment and management; sustainable construction materials; and environmental management.

Dickson Y. S. YAN, Teaching Fellow at the Faculty of Science and Technology, the Technological and Higher Education Institute of Hong Kong. He obtained his $\mathrm{PhD}$ in Environmental Engineering from The Hong Kong University of Science and Technology in 2013 and has published about 10 scientific papers. Research interests: carbon footprint assessment on remediation technology; life cycle assessment of products and production lines; waste material recycling and reuse; nanotechnology for environmental application; waste disposal and treatment; and remediation of contaminated soils, sediments and groundwater.

Irene M. C. LO, Professor at the Department of Civil and Environmental Engineering, Hong Kong University of Science and Technology. She is currently Academician of European Academy of Sciences and Arts and Chairman of Environmental Division, the Hong Kong Institution of Engineers. Research interests: remediation of contaminated soils, sediments and groundwater; waste material recycling and reuse; nanoparticle transport and fate; nanotechnology for environmental application; waste disposal and treatment; carbon footprint assessment on remediation technology; construction carbon management and reduction measures; and life cycle assessment of products and production lines.

Tongzhou LIU, Associate Professor at Harbin Institute of Technology Shenzhen Graduate School. He received his PhD degree in Environmental Engineering from The Hong Kong University of Science and Technology in 2009 and has published more than 10 scientific papers. Research interests include fate and transport of contaminants in subsurface environment; contaminants control in sediment and dredge materials; remediation of contaminated site and river; and physicochemical processes for recalcitrant contaminants control. 